\title{
HUBUNGAN PEMBANGUNAN MANUSIA DAN PERTUMBUHAN EKONOMI DI MALUKU PADA MASA PANDEMI COVID-19
}

\author{
The Relationship of Human Development and Economic Growth in Maluku \\ During the Covid-19 Pandemic
}

\author{
Arnelia Palijama* \\ Badan Pusat Statistik (BPS) Provinsi Maluku \\ Jalan Wolter Monginsidi, Passo, Ambon, 97232 \\ Corresponding authore-mail: *arnelia@bps.go.id
}

\begin{abstract}
Abstrak
Pembangunan ekonomi suatu daerah bertujuan untuk memperoleh pertumbuhan ekonomi tinggi, yang dapat mendorong peningkatan pendapatan per kapita penduduk yang diikuti dengan peningkatan pembangunan manusia. Tujuan penelitian ini untuk mengetahui pengaruh pertumbuhan ekonomi terhadap kinerja pembangunan manusia di Provinsi Maluku selama periode pandemi Covid-19. Penelitian menggunakan pendekatan kuantitatif dengan metode analisis deskriptif dan inferensial. Teknik analisis regresi linear sederhana diterapkan untuk mengetahui hubungan antara IPM terhadap pertumbuhan ekonomi dan dipetakan dalam peta kuadran. Temuan yang didapatkan menggambarkan pertumbuhan IPM di Maluku tahun 2020 melambat 0,06 persen, sedangkan pertumbuhan ekonomi terkontraksi mencapai 0,92 persen. Tidak terdapat kabupaten/kota yang IPM dan pertumbuhan ekonominya yang lebih rendah dari angka Provinsi Maluku. Sekitar 81 persen kabupaten/kota terpetakan pada Kuadaran II (IPM lebih rendah dan pertumbuhan ekonomi lebih tinggi dari angka Maluku). Hasil estimasi persamaan regreasi mengkonfirmasi hubungan yang sangat kuat. Hasil penelitian mengindikasikan pandemi Covid-19 berdampak pada perlambatan pertumbuhan IPM Provinsi Maluku pada tahun 2020.
\end{abstract}

Kata Kunci : Tahun pandemi, pembangunan manusia, pembangunan ekonomi

\section{Abstract}

The economic development of a region aims to obtain high economic growth, which can encourage an increase in the income per capita of the population followed by an increase in human development. The purpose of this study was to determine the effect of economic growth on human development performance in Maluku Province during the Covid19 pandemic period. The research uses a quantitative approach with descriptive and inferential analysis methods. Simple linear regression analysis technique was applied to determine the relationship between HDI and economic growth and mapped it on a quadrant map. The findings obtained illustrate that the HDI growth in Maluku in 2020 slowed to 0.06 percent, while economic growth contracted to 0.92 percent. There are no districts/cities whose HDI and economic growth are lower than the Maluku Province figure. Around 81 percent of districts/cities are mapped in Quadrant II (lower HDI and higher economic growth than the Maluku figure). The estimation results of the regression equation confirm a very strong relationship. The results of the study indicate that the Covid-19 pandemic has an impact on the slowdown in the HDI growth of Maluku Province in 2020.

Keywords: Pandemic year, human development, economic development 


\section{PENDAHULUAN}

Aset paling strategis dari suatu bangsa dan negara adalah sumber daya manusia. Ketersediaan sumber daya alam (natural resources) bukan semata menjadi tumpuan kemajuan suatu bangsa dan negara, melainkan ditentukan juga dari kualitas sumber daya manusia. Kualitas sumber daya manusia antaranya didapat melalui kesehatan dan pendidikan. Manusia yang kualitas kesehatannya relatif lebih baik, memungkinkannya untuk mengenyam pendidikan. Pendidikan yang rendah berimbas pada kualitas sumber daya manusia rendah, sementara pendidikan yang makin tinggi akan berimbas pada kualitas sumber daya manusia yang makin tinggi pula. Pendidikan tinggi memungkinkan manusia mendapatkan pekerjaan dengan pendapatan relatif lebih tinggi, dan dengan pendapatan yang relatif tinggi memungkinkan manusia untuk men-service kesehatannya relatif lebih baik[1].

Manusia dengan sumber dayanya telah menjadi bagian dalam paradigma pembangunan. Dewasa ini, tidak heran jika fokus dari pemerintah di Indonesia berpusat pada pembangunan manusia (human centered development). Indonesia mengalami pergeseran pemikiran kebijakan pembangunannya, yakni dari production-centered development ke distribution-growth development, berganti ke basic need development, dan terakhir ini ke human-centered development [1]. Pembangunan ekonomi, pembangunan infrastruktur, dan pembangunan di lini lainnya, pemerintah tujukan semata-mata untuk peningkatan pembangunan manusia Indonesia. Pemerintah berkomitmen pada peningkatan quality of life penduduk Indonesia.

United Nations Development Program (UNDP) mengukur pembangunan manusia dengan menggunakan Indeks Pembangunan Manusia (IPM). IPM menjelaskan bagaimana penduduk dapat mengakses hasil pembangunan dalam memperoleh pendapatan, kesehatan, pendidikan, dan sebagainya (BPS). IPM dibentuk oleh tiga dimensi dasar: dimensi kesehatan diukur dengan indikator umur harapan hidup saat lahir; dimensi pendidikan diukur dengan indikator harapan lama sekolah dan rata-rata lama sekolah; serta dimensi standar hidup layak diukur dengan indikator pengeluaran per kapita per tahun yang disesuaikan.

IPM sebagai salah satu indikator yang digunakan mengukur taraf kualitas fisik serta non fisik dari penduduk [2], memiliki beberapa manfaat. Selain bermanfaat untuk mengukur keberhasilan upaya membangun kualitas hidup manusia (masyarakat/penduduk). Di Indonesia, IPM bermanfaat sebagai indikator target pembangunan pemerintah dalam pembahasan asumsi makro di DPR-RI. Digunakan juga sebagai penentu Dana Alokasi Umum (DAU). Serta, penghitungan Dana Insentif Daerah (DID) menggunakan indikator dari komponen IPM (harapan lama sekolah, rata-rata lama sekolah, dan pengeluaran).

Pembangunan manusia berbeda antar setiap provinsi di Indonesia. Maluku sebagai salah satu provinsi di Indonesia, pada masa pandemi Covid-19 di tahun 2020, pembangunan manusianya yang di-proksi dengan IPM menduduki peringkat 26 dari 34 provinsi. Walau berada pada peringkat demikian, tidak terdapat lagi status pembangunan manusia "rendah" di Maluku.

Ranis (2004)[3] dalam Lumbantoruan \& Hidayat (2013)[4] menjelaskan bahwa pembangunan manusia memperoleh manfaat langsung dari pertumbuhan ekonomi melalui peningkatan pendapatan. Pendapatan dalam IPM di proksi dengan pengeluaran per kapita per tahun yang disesuaikan. Pertumbuhan ekonomi erat dengan pembangunan manusia. Penulis tertarik untuk melakukan penelitian yang mengkaji pengaruh pertumbuhan ekonomi terhadap IPM di Provinsi Maluku pada masa pandemi Covid-19 di tahun 2020.

Penelitian yang mengkaji hubungan pertumbuhan ekonomi dan IPM telah dikaji oleh beberapa peneliti [2][4-7]. Akan tetapi, penulis belum menemukan penelitian yang mengkaji pengaruh IPM terhadap pertumbuhan ekonomi di Provinsi Maluku selama tahun pandemi Covid-19[8-11].

\section{METODE PENELITIAN}

Penelitian ini menggunakan pendekatan kuantitatif, dengan metode analisis statistik deskriptif dan analisis inferensial. Statistik deskriptif walau sederhana, tetapi dapat dijadikan masukan untuk pengambil keputusan [12], sehingga dalam penelitian ini dipakai untuk memberikan gambaran IPM dan pertumbuhan ekonomi menurut kabupaten/kota di Maluku tahun 2020. Statistik inferensial dalam penelitian ini untuk mencoba menarik kesimpulan [13] korelasi antara IPM dan pertumbuhan ekonomi. Serta untuk mengetahui pengaruh variabel bebas terhadap variabel terikat [14] digunakan teknik analisis regresi linear sederhana. Persamaan regresi yang dibentuk adalah sebagai berikut: 


$$
Y=a+b X+e
$$

$Y=I P M$

$a=$ Konstanta

$b=$ Koefisien Regresi

$X=$ pertumbuhan ekonomi

$e=$ error regresi yang diasumsikan berdistribusi normal dengan varian konstan dan tanpa autokorelasi

Peta kuadran digunakan dalam penelitian ini ntuk melihat pengelompokan kabupaten/kota berdasarkan IPM dan pertumbuhan ekonomi [15]. Diagram kartesius membedakan angka IPM dan pertumbuhan ekonomi dari kabupaten/kota dalam empat kelompok kuadran, yaitu Kuadran I IPM dan pertumbuhan ekonomi yang lebih tinggi dari angka Maluku; Kuadran II IPM lebih rendah dan pertumbuhan ekonomi lebih tinggi dari angka Maluku; Kuadran III IPM dan pertumbuhan ekonomi yang lebih rendah dari angka Maluku; serta Kuadran IV IPM yang lebih tinggi dan pertumbuhan ekonomi lebih rendah dari angka Maluku.

Sumber data sekunder diperoleh dari Badan Pusat Statistik (BPS) Provinsi Maluku [16-17], yakni data IPM dan pertumbuhan ekonomi menurut kabupaten/kota di Maluku tahun 2020. IPM dihitung menggunakan indikator umur harapan hidup saat lahir (UHH), harapan lama sekolah (HLS), rata-rata lama sekolah (RLS), dan pengeluaran per kapita per tahun yang disesuaikan. Sedangkan, pertumbuhan ekonomi adalah laju pertumbuhan Produk Domestik Regional Bruto (PDRB) yang diperoleh dari perhitungan PDRB atas dasar harga konstan. Laju pertumbuhan tersebut dihitung dengan cara mengurangi nilai PDRB pada tahun ke-n terhadap nilai pada tahun ke n-1 (tahun sebelumnya), dibagi dengan nilai pada tahun ke n-1, kemudian dikalikan dengan 100 persen.

\section{HASIL DAN PEMBAHASAN}

Gambaran pembangunan manusia dapat diukur dengan indikator IPM (UNDP, 1990). Besaran angka IPM Maluku di tahun pandemi Covid-19 yakni pada tahun 2020 mencapai 69,49 dengan status pembangunan manusia "sedang". Pembangunan manusia Maluku meningkat dibandingkan tahun $2019(69,45)$, akan tetapi pertumbuhannya melambat sebesar 0,06 persen (rata-rata per tahun 0,78 persen). Pertumbuhan IPM Maluku di tahun 2020 merupakan yang terendah selama sepuluh tahun terakhir ini. Perlambatan pertumbuhan ini disebabkan oleh menurunnya pengeluaran per kapita per tahun yang disesuaikan sebesar 155 ribu dari 8,89 juta rupiah ke 8,73 juta rupiah.

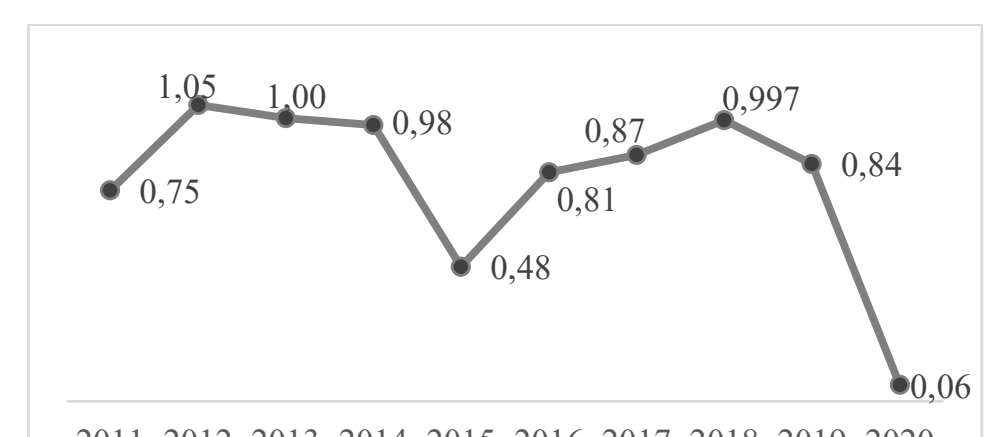

2011201220132014201520162017201820192020

Gambar 1. Persentase Pertumbuhan IPM di Maluku, 2011-2020

IPM tertinggi di Maluku ditempati oleh Kota Ambon, sedangkan daerah dengan IPM terendah adalah Kabupaten Maluku Barat Daya. Sekitar 18 persen atau sebanyak dua kabupaten/kota di Maluku memiliki angka IPM di atas angka IPM Maluku, dengan status pembangunan manusia "tinggi" dan "sangat tinggi". Sisanya 9 kabupaten/kota atau sekitar 82 persen berstatus pembangunan manusia "sedang" dengan angka IPM di bawah angka IPM Maluku. 
Tabel 1. IPM Menurut Kabupaten/Kota di Maluku, 2019-2020

\begin{tabular}{lll}
\hline \multirow{2}{*}{ Kabupaten/Kota } & \multicolumn{2}{c}{ IPM } \\
\cline { 2 - 3 } Kepulauan Tanimbar & $\mathbf{2 0 1 9}$ & $\mathbf{2 0 2 0}$ \\
\hline Maluku Tenggara & 62,86 & 62,86 \\
\hline Maluku Tengah & 65,85 & 66,20 \\
\hline Buru & 71,25 & 71,25 \\
\hline Kepulauan Aru & 68,91 & 68,95 \\
\hline Seram Bagian Barat & 63,64 & 63,71 \\
\hline Seram Bagian Timur & 65,49 & 65,62 \\
\hline Maluku Barat Daya & 63,74 & 64,12 \\
\hline Buru Selatan & 61,55 & 61,90 \\
\hline Ambon & 64,42 & 64,69 \\
\hline Tual & 80,81 & 80,84 \\
\hline \multicolumn{1}{c}{ Maluku } & 67,74 & 67,96 \\
\hline Sumber data: BPS Provins & 69,45 & 69,49 \\
\hline
\end{tabular}

Sumber data: BPS Provinsi Maluku

Dirinci berdasarkan indikator pembentuk IPM, untuk dimensi kesehatan dan dimensi pendidikan tahun 2020 mengalami peningkatan dibandingkan tahun 2019. Hanya dimensi standar hidup layak yang diwakili oleh indikator pengeluaran per kapita per tahun yang disesuaikan, mengalami penurunan pada hampir seluruh kabupaten/kota di Maluku. Hingga berimbas pada dua kabupaten yakni Kepulauan Tanimbar dan Maluku Tengah stagnan tidak mengalami peningkatan angka IPM. Stagnan peningkatan IPM kedua kabupaten ini, mengindikasikan dampak Covid-19 yang mempengaruhi daya beli masyarakat.

Tabel 2. Indikator Pembentuk IPM Menurut Kabupaten/Kota, 2019-2020

\begin{tabular}{|c|c|c|c|c|c|c|c|c|}
\hline \multirow[t]{2}{*}{ Kabupaten/Kota } & \multicolumn{2}{|c|}{ UHH } & \multicolumn{2}{|c|}{ HLS } & \multicolumn{2}{|c|}{ RLS } & \multicolumn{2}{|c|}{$\begin{array}{c}\text { Pengeluaran per } \\
\text { Kapita per Tahun yang } \\
\text { Disesuaikan (Rp) }\end{array}$} \\
\hline & 2019 & 2020 & 2019 & 2020 & 2019 & 2020 & 2019 & 2020 \\
\hline Kepulauan Tanimbar & 63,34 & 63,42 & 12,28 & 12,29 & 9,55 & 9,68 & 6.396 .000 & 6.297 .000 \\
\hline Maluku Tenggara & 64,95 & 65,07 & 12,63 & 12,81 & 9,50 & 9,73 & 7.625 .000 & 7.545 .000 \\
\hline Maluku Tengah & 66,34 & 66,42 & 14,15 & 14,16 & 9,64 & 9,67 & 10.298 .000 & 10.210 .000 \\
\hline Buru & 66,32 & 66,41 & 13,02 & 13,03 & 8,46 & 8,52 & 10.400 .000 & 10.316 .000 \\
\hline Kepulauan Aru & 62,73 & 62,87 & 12,29 & 12,30 & 8,71 & 8,82 & 7.678 .000 & 7.586 .000 \\
\hline Seram Bagian Barat & 61,48 & 61,69 & 13,42 & 13,44 & 8,86 & 8,87 & 8.704 .000 & 8.690 .000 \\
\hline Seram Bagian Timur & 59,16 & 59,41 & 12,75 & 12,76 & 8,22 & 8,43 & 9.452 .000 & 9.453 .000 \\
\hline Maluku Barat Daya & 62,16 & 62,38 & 12,26 & 12,27 & 8,14 & 8,35 & 6.888 .000 & 6.890 .000 \\
\hline Buru Selatan & 66,13 & 66,27 & 12,68 & 12,69 & 7,70 & 7,94 & 7.627 .000 & 7.566 .000 \\
\hline Ambon & 70,35 & 70,52 & 16,02 & 16,03 & 11,91 & 11,92 & 14.233 .000 & 14.116 .000 \\
\hline Tual & 65,21 & 65,47 & 13,90 & 13,97 & 10,26 & 10,52 & 7.506 .000 & 7.351 .000 \\
\hline Maluku & 65,82 & 65,98 & 13,94 & 13,96 & 9,81 & 9,93 & 8.887 .000 & 8.732 .000 \\
\hline
\end{tabular}

Sumber data: BPS Provinsi Maluku 
Sementara itu, laju pertumbuhan ekonomi Maluku di tahun pandemi Covid-19 pada tahun 2020 ini menunjukkan arah negatif. Ekonomi Maluku mengalami kontraksi hingga hampir satu persen, dibandingkan tahun 2019 yang positif 5,41 persen. Searah dengan laju pertumbuhan ekonomi Maluku, seluruh kabupaten/kota di Maluku pun menunjukkan arah negatif, dibandingkan tahun 2019 yang positif. Daerah di Maluku dengan pertumbuhan ekonomi negatif terdalam mencapai hampir 2 persen dialami oleh Kota Ambon. Sedangkan daerah dengan pertumbuhan ekonomi negatif terendah mencapai 0,01 persen dialami oleh Kabupaten Buru Selatan. Hanya Kota Ambon yang memiliki pertumbuhan ekonomi negatif yang lebih tinggi dibandingkan angka pertumbuhan ekonomi Maluku. Sisanya, 10 kabupaten/kota atau sekitar 91 persen, memiliki pertumbuhan ekonomi negatif yang lebih rendah dari pertumbuhan ekonomi Maluku.

Tabel 3. Pertumbuhan Ekonomi Menurut Kabupaten/Kota di Maluku, 2019-2020

\begin{tabular}{lll}
\hline \multirow{2}{*}{ Kabupaten/Kota } & \multicolumn{2}{c}{ Pertumbuhan Ekonomi } \\
\cline { 2 - 3 } & $\mathbf{2 0 1 9}$ & $\mathbf{2 0 2 0}$ \\
\hline Kepulauan Tanimbar & 5,98 & $-0,03$ \\
\hline Maluku Tenggara & 5,85 & $-0,22$ \\
\hline Maluku Tengah & 5,83 & $-0,40$ \\
\hline Buru & 6,06 & $-0,02$ \\
\hline Kepulauan Aru & 5,82 & $-0,04$ \\
\hline Seram Bagian Barat & 5,56 & $-0,17$ \\
\hline Seram Bagian Timur & 1,00 & $-0,06$ \\
\hline Maluku Barat Daya & 5,99 & $-0,13$ \\
\hline Buru Selatan & 5,88 & $-0,01$ \\
\hline Ambon & 5,78 & $-1,95$ \\
\hline Tual & 5,87 & $-0,18$ \\
\hline \multicolumn{1}{c}{ Maluku } & 5,41 & $-0,92$ \\
\hline Sur da: BPS Provin
\end{tabular}

Sumber data: BPS Provinsi Maluku

Jika dilihat dari hubungan antara IPM terhadap pertumbuhan ekonomi di tahun pandemi Covid-19 dengan menggunakan regersi linear sederhana, didapat bahwa nilai $\mathrm{p}$ (signifikansi) sangat kuat, yaitu sebesar 0,000163 . Hal ini menunjukkan bahwa adanya pengaruh yang sangat kuat antara IPM terhadap pertumbuhan ekonomi. Pengaruh yang sangat kuat ditunjukkan juga dengan besaran $\mathrm{R}^{2}$ yang cukup tinggi sebesar 0,809 , artinya IPM berpengaruh terhadap pertumbuhan ekonomi sebesar 80,9 persen, sisanya $(19,1$ persen) dipengaruhi oleh variabel lain yang belum tercantum dalam model. Hal ini diperkuat dengan penelitian yang dilakukan oleh Maratade, dkk (2016)[6] yang menunjukkan bahwa terdapat hubungan kausalitas antara pertumbuhan ekonomi dan IPM, juga sebaliknya IPM mempunyai hubungan kausalitas dengan pertumbuhan ekonomi.

Tabel 4. Hasil Estimasi Regresi Linear Sederhana IPM dengan Pertumbuhan Ekonomi Menurut Kabupaten/Kota di Maluku, 2020

\begin{tabular}{|c|c|}
\hline Uraian & Nilai \\
\hline Sig./p value & $0,000163^{b}$ \\
\hline $\mathbf{F}$ & 38,179 \\
\hline $\mathbf{R}$ & $0,899576^{\mathrm{b}}$ \\
\hline $\mathbf{R}^{2}$ & 0,809237 \\
\hline Std. Error & 2,48756 \\
\hline
\end{tabular}

a. Dependent Variable: IPM (Y)

b. Predictors: (Constant), pertumbuhan ekonomi (X) 
Selanjutnya, jika IPM dan pertumbuhan ekonomi divisualisasikan menggunakan scatter plot diperoleh seperti pada Gambar 2, dapat diketahui sebaran IPM dan pertumbuhan ekonomi di Maluku di tahun pandemi Covid-19. Terdapat satu daerah yakni Kabupaten Maluku Tengah yang masuk dalam klasifikasi Kuadran I, baik IPM maupun pertumbuhan ekonomi kabupaten tersebut lebih tinggi dari angka provinsi. Kabupaten Maluku Tengah berstatus pembangunan manusia "tinggi". Harapan hidup saat lahir di Kabupaten Maluku Tengah mencapai 66,42 tahun, meningkat dibandingkan tahun 2019 (66,34 tahun), dan lebih tinggi dari angka Provinsi Maluku yang sebesar 65,98 tahun. Informasi ini mengindikasikan belum berdampaknya Covid-19 terhadap kualitas kesehatan di Kabupaten Maluku Tengah. Dari segi pendidikan, harapan lama sekolah dan rata-rata lama sekolah di kabupaten ini masing-masing sebesar 14,16 tahun dan 9,67 tahun. Anak-anak usia tujuh tahun memiliki peluang untuk menamatkan pendidikan mereka hingga lulus SMA atau D2. Sementara, rata-rata penduduk usia 25 tahun ke atas telah mengenyam pendidikan selama 9,67 tahun (setara kelas IX). Kedua indikator pendidikan ini pun mengalami peningkatan dibandingkan tahun 2019 (14,15 tahun dan 9,64 tahun), yang menjadi indikasi bahwa pandemi Covid-19 belum berdampak terhadap harapan pendidikan di Maluku Tengah. Dari sisi ekonomi, pengeluaran per kapita per tahun yang disesuaikan Kabupaten Maluku Tengah lebih tinggi dari angka Provinsi Maluku, tercatat mencapai 10,21 juta rupiah atau ditemukan turun 88 ribu rupiah dibandingkan tahun 2019 yang sebesar 10,30 juta rupiah. Turunnya pengeluaran per kapita per tahun yang disesuaikan mengindikasikan dampak pandemi Covid-19 terhadap daya beli penduduk di Kabupaten Maluku Tengah, sebagaimana dapat terlihat juga dari pertumbuhan ekonomi yang terkontraksi mencapai 0,40 persen.

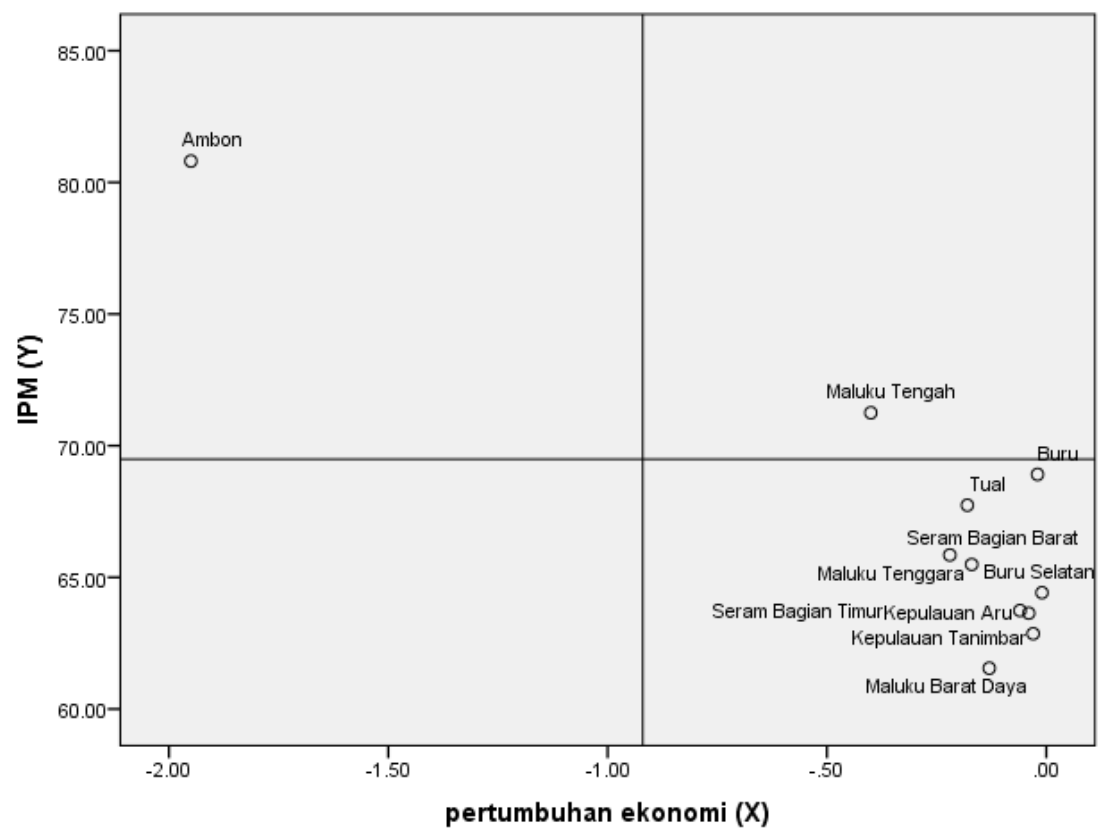

Gambar 2. Scater Plot IPM dan Pertumbuhan Ekonomi Menurut Kabupaten/Kota di Maluku, 2020

Hasil scater plot berikutnya yaitu Kuadran II, daerah dengan IPM lebih rendah dan pertumbuhan ekonomi lebih tinggi dari angka Maluku. Ada sembilan kabupaten/kota yang masuk ke dalam Kuadran II, antara lain Kabupaten Kepulauan Tanimbar, Kabupaten Maluku Tenggara, Kabupaten Buru, Kabupaten Kepulauan Aru, Kabupaten Seram Bagian Barat, Kabupaten Seram Bagian Timur, Kabupaten Maluku Barat Daya, Kabupaten Buru Selatan, dan Kota Tual. Harapan hidup saat lahir dari kesembilan kabupaten/kota ini masing-masing mencapai 63,42 tahun, 65,07 tahun, 66,41 tahun, 62,87 tahun, 61,69 tahun, 59,41 tahun, 62,38 tahun, 66,27 tahun, dan 65,47 tahun. Umur harapan hidup saat lahir dari kesembilan kabupaten/kota ini meningkat dibandingkan tahun 2019. Ini mengindikasikan kualitas kesehatan di kesembilan daerah belum terdampak pandemi Covid-19. Namun hanya dua daerah yaitu Kabupaten Buru dan Kabupaten Buru Selatan yang harapan lama hidup saat lahir lebih tinggi dari angka Maluku yang sebesar 65,98 tahun, sehingga untuk ketujuh daerah lainnya perlu di-push pembangunan kesehatannya.

Dari segi pendidikan kabupaten/kota di Kuadran II, harapan lama sekolah masing-masing sebesar 12,29 tahun, 12,81 tahun, 13,03 tahun, 12,30 tahun, 13,44 tahun, 12,76 tahun, 12,27 tahun, 12,69 tahun dan 
13,97 tahun. Anak-anak usia tujuh tahun dari kesembilan kabupaten/kota ini memiliki peluang untuk menamatkan pendidikan mereka masing-masing di Kabupaten Kepulauan Tanimbar hingga lulus SMA; Kabupaten Maluku Tenggara hingga lulus SMA; Kabupaten Buru hingga lulus SMA atau D1; Kabupaten Kepulauan Aru hingga lulus SMA; Kabupaten Seram Bagian Barat hingga lulus SMA atau D1; Kabupaten Seram Bagian Timur hingga lulus SMA; Kabupaten Buru Selatan hingga lulus SMA; dan Kota Tual hingga lulus SMA atau D1. Penduduk di kabupaten/kota pada Kuadran II cukup berpendidikan. Rata-rata lama sekolah penduduk usia 25 tahun ke atas yang telah mengenyam pendidikan masing-masing di Kepulauan Tanimbar selama 9,68 tahun (setara kelas IX); Kabupaten Maluku Tenggara selama 9,73 tahun (setara kelas IX); Kabupaten Buru selama 8,52 tahun (setara kelas VIII); Kabupaten Kepulauan Aru selama 8,82 tahun (setara kelas VIII); Kabupaten Seram Bagian Barat selama 8,87 tahun (setara kelas VIII); Kabupaten Seram Bagian Timur 8,43 tahun (setara kelas VIII); Kabupaten Maluku Barat Daya selama 8,35 tahun (setara kelas VIII); Kabupaten Buru Selatan selama 7,94 tahun (setara kelas VII); dan Kota Tual selama 10,52 tahun (setara kelas X). Temuan ini mengindikasikan bahwa pandemi Covid-19 belum berdampak pada harapan pendidikan kesembilan kabupaten/kota di Kuadran II.

Dari sisi ekonomi di Kuadran II, rata-rata pengeluaran per kapita per tahun yang disesuaikan Kabupaten Kepulauan Tanimbar, Kabupaten Maluku Tenggara, Kabupaten Kepulauan Aru, Kabupaten Seram Bagian Barat, Kabupaten Maluku Barat Daya, Kabupaten Buru Selatan dan Kota Tual lebih rendah dibandingkan angka Provinsi Maluku. Berbeda dengan Kabupaten Buru dan Kabupaten Seram Bagian Timur yang memiliki pengeluaran per kapita per tahun yang disesuaikan lebih tinggi dari angka Provinsi Maluku. Namun di tahun pandemi Covid-19, pengeluaran per kapita per tahun yang disesuaikan mengalami penurunan dibandingkan tahun 2019, hanya Kabupaten Seram Bagian Timur dan Kabupaten Maluku Barat Daya yang mengalami kenaikan. Terindikasikan pandemi covid-19 tidak mempengaruhi daya beli penduduk di Kabupaten Seram Bagian Timur dan Kabupaten Maluku Barat Daya.

Kemudian pada Kuadran III, tidak terdapat kabupaten/kota dengan IPM dan pertumbuhan ekonomi yang lebih rendah dari angka Maluku. Temuan indikasi pada kuadran III ini, pandemi Covid-19 belum mengakibatkan kabupaten/kota di Maluku menjadi tertinggal. Sinergitas antara Provinsi Maluku serta kabupaten/kota harus tetap selalu dipertahankan agar permasalahan multidimensi semasa pandemi Covid-19 dapat tertangani.

Terakhir untuk Kuadran IV, daerah dengan IPM yang lebih tinggi dan pertumbuhan ekonomi lebih rendah dari angka Maluku yang terpetakan adalah Kota Ambon. Kota Ambon lebih maju pembangunan manusianya di antara kabupaten/kota di Maluku. Harapan hidup saat lahir di Kota Ambon mencapai 70,52 tahun, meningkat dibandingkan tahun 2019 (70,35 tahun), serta lebih tinggi dari angka Provinsi Maluku yang sebesar 65,98 tahun. Temuan ini mengindikasikan bahwa di tengah pandemi Covid-19, kualitas kesehatan semakin baik, dengan penanganan Covid-19 yang tetap terus diperhatikan. Dari segi pendidikan, harapan lama sekolah di kota ini sebesar 16,03 tahun yang berarti bahwa anak-anak usia 7 tahun memiliki peluang untuk menamatkan pendidikan mereka hingga lulus D4 atau S1. Penduduk usia 25 tahun ke atas rata-rata telah mengenyam pendidikan selama 11,92 tahun (setara kelas XI). Terindikasi pandemi Covid-19 belum mempengaruhi harapan pendidikan di Maluku. Dari sisi ekonomi, pengeluaran per kapita per tahun yang disesuaikan mencapai 14,12 juta rupiah menurun 117 ribu dibandingkan tahun 2019, tetapi lebih tinggi dari angka Provinsi Maluku. Turunnya pengeluaran per kapita per tahun yang disesuaikan dari Kota Ambon, mengindikasikan bahwa pandemi Covid-19 berdampak pada daya beli masyarakatnya.

Hasil penelitian ini memerlukan penelitian lebih lanjut, karena pandemi masih berlangsung ketika penelitian ini dilakukan. Penelitian lebih lanjut dapat menggunakan model regreresi data panel untuk meningkatkan jumlah observasi. Selain itu, sejumlah variabel kontrol dapat ditambahkan pada model regresi IPM dan pertumbuhan ekonomi.

\section{KESIMPULAN}

Terdapat beberapa temuan penting dari penelitian ini. Dari sisi pembangunan manusia, terjadi perlambatan pertumbuhan IPM disebabkan oleh turunnya pengeluaran per kapita per tahun yang disesuaikan, yang menjadi indikasi dampak pandemi Covid-19 terhadap daya beli masyarakat. Sejalan dengan turunnya pengeluaran per kapita per tahun yang disesuaikan dari IPM, ekonomi Maluku pun terkontraksi negatif pertumbuhannya. Hasil penelitian juga menunjukkan adanya pengaruh yang sangat kuat dari IPM terhadap pertumbuhan ekonomi di Maluku, yang ditunjukkan dengan nilai p (signifikansi) sebesar 0,000163. 
Selanjutnya besaran $\mathrm{R}^{2}$ yang sangat tinggi menunjukkan bahwa IPM sangat dipengaruhi oleh pertumbuhan ekonomi. Dilihat dari pola persebarannya, tidak terdapat kabupaten/kota yang memiliki angka IPM dan pertumbuhan ekonomi yang lebih rendah dari angka Maluku. Dengan demikian, Pemerintah Provinsi Maluku serta Pemerintah Kabupaten/Kota hendaknya bersinergi mengawal penanganan pandemi Covid-19 untuk pencegahan penularan menuju zero pasien.

\section{DAFTAR PUSTAKA}

[1] U. Silalahi, "Relevansi Kebijakan Human-Centered Development Dan Perbaikan Kualitas Pendidikan Dalam Pengembangan Kualitas Sumberdaya Manusia Indonesia," Adm. Negara, vol. 2, no. April 2003, hal. 87-107, 2003.

[2] M. Muqorrobin, "PENGARUH INDEKS PEMBANGUNAN MANUSIA (IPM) TERHADAP PERTUMBUHAN EKONOMI PROVINSI JAWA TIMUR," Pendidik. Ekon., vol. 5, no. 3, 2017.

[3] G. Ranis, "Human Development and Economic Growth," Elgar Companion to Dev. Stud., 2004, doi: $10.4337 / 9781847202864.00061$.

[4] E. P. Lumbantoruan dan P. Hidayat, "ANALISIS PERTUMBUHAN EKONOMI DAN INDEKS PEMBANGUNAN MANUSIA (IPM) PROVINSI-PROVINSI DI INDONESIA (METODE KOINTEGRASI),” J. Ekon. dan Keuang., vol. 2, no. 2, hal. 7-31, 2013

[5] N. L. S. Dewi dan I. K. Sutrisna, "Pengaruh Komponen Indeks Pembangunan Manusia Terhadap Pertumbuhan Ekonomi Provinsi Bali," E-Jurnal EP Unud, vol. 3, hal. 106-114, 2014.

[6] S. Y. Maratade, D. C. Rotinsulu, A. O. Niode, J. E. Pembangunan, F. Ekonomi, dan D. Bisnis, "Analisis Pertumbuhan Ekonomi Dan Indeks Pembangunan Manusia Di Provinsi Sulawesi Utara ( Studi Pada Tahun 2002-2013 ),” J. Berk. Ilm. Efisiensi, vol. 16, no. 01, hal. 328-338, 2016.

[7] A. G. Brata, "Pembangunan Manusia dan Kinerja Ekonomi Regional Di Indonesia," J. Ekon. Pembang., vol. 7, no. 2, hal. 113$122,2002$.

[8] R. N. AZIMAH, I. N. KHASANAH, R. PRATAMA, Z. AZIZAH, W. FEBRIANTORO, dan S. R. S. PURNOMO, "Analisis Dampak Covid-19 Terhadap Sosial Ekonomi Pedagang Di Pasar Klaten Dan Wonogiri,” EMPATI J. Ilmu Kesejaht. Sos., vol. 9, no. 1, hal. 59-68, 2020, doi: 10.15408/empati.v9i1.16485.

[9] H. A. Yanuarita dan S. Haryati, "Pengaruh Covid-19 Terhadap Kondisi Sosial Budaya Di Kota Malang Dan Konsep Strategis Dalam Penanganannya,” J. Ilm. Widya Sosiopolitika, vol. 2, no. 2, hal. 58, 2021, doi: 10.24843/jiwsp.2020.v02.i02.p01.

[10] W. Hadiwardoyo, "Kerugian Ekonomi Nasional Akibat Pandemi Covid-19," Baskara J. Bus. Entrep., vol. 2, no. 2, hal. 83-92, 2020, doi: 10.24853/baskara.2.2.83-92.

[11] S. Rahmadia dan N. Febriyani, "Dampak covid-19 terhadap ekonomi," J. Ekon. Islam. Islam., hal. 4-9, 2020, [Daring]. Tersedia pada: http://www.academia.edu/download/63607873/19011040100113_Shinta_Rahmadia_Paper_Ekonomi_Makro20200612 -116816-16qfxl2.pdf.

[12] I. G. N. Agung, “Analisis Statistik Sederhana Untuk Pengambilan Keputusan,” Populasi, vol. 11, no. 2, 2016, doi: 10.22146/jp.12342.

[13] A. Sholikhah, "Statistik Deskriptif Dalam Penelitian Kualitatif," KOMUNIKA J. Dakwah dan Komun., vol. 10, no. 2, hal. 342 362, 2016, doi: 10.24090/komunika.v10i2.953.

[14] E. Putra, "Pengaruh Harga Terhadap Kepuasan Kosumen Pada Citra Swalayan Dengan Variabel Intervening Service Quality," E-Jurnal Apresiasi Ekonomi. hal. 89-94, 2014.

[15] L. Sugiyono, “Analisis Situasi Pembangunan Manusia di Jawa Tengah,” Indones. J. Appl. Stat., vol. 3, no. 1, hal. 12, 2020, doi: 10.13057/ijas.v3i1.39910.

16] BPS Provinsi Maluku. "Indeks Pembangunan Manusia Menurut Kabupaten/Kota di Provinsi Maluku 2020", 24 Maret 2021 [Online]. Tersedia: https://maluku.bps.go.id/indicator/26/216/1/indeks-pembangunan-manusia-menurut-kabupaten-kota-diprovinsi-maluku.html [Diakses: 24 Maret 2021]

[17] BPS Provinsi Maluku. "Produk Domestik Regional Bruto Kabupaten/Kota di Maluku 2020", 31 Mei 2021 [Online]. Tersedia: https://maluku.bps.go.id/publication/2021/05/31/c803ff2ddcf02d0ac0c9d449/produk-domestik-regional-bruto-kabupatenkota-di-maluku-menurut-lapangan-usaha-2016---2020.html [Diakses: 31 Mei 2021] 